\title{
The Experience of Implementing Sport Education Model 競技運動模式之實践經驗
}

\author{
Alberto CRUZ \\ Department of Creative Arts and Physical Education \\ The Hong Kong Institute of Education, HONG KONG
}

高蓬倫

香港教育學院體藝學系

\begin{abstract}
Sport education has attracted attention and interest from physical educators recently. However, the implementation of sport education has not been without difficulties. The purposes of this study were to understand the views of teachers and students on this model as well as examining the difficulties the teachers may face when implementing the model. Two secondary physical education teachers and 110 secondary students participated in the study. The teachers taught a unit of football lessons in sport education to two classes of students. They were requested to keep a reflective journal that focused on the process of implementation of the approach as well as the student reaction to this model. An interview focused on their views of using the approach was conducted with each teacher. Views of students toward the instructional approach were also obtained through the use of a structured questionnaire. Results revealed that the major difficulty faced by the teachers was the planning before the implementation. Most students expressed that they favoured the model and understood more about the organizing of football games. They also valued the learning of collaboration skills and team spirits in the lessons. The findings hold implications for the physical educators and teacher educators in Hong Kong.
\end{abstract}

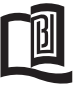

\section{摘要}

本研究目的是探討體育教師和中學生對競技運動模式的觀感與及教師在實踐此模式所遇上的困難。兩位中學老師及其學生參 與是次研究。老師運用競技運動模式(足球單元)教授兩班學生。老師利用反思日誌記錄實踐感想及學生反應。老師其後以訪問形式 表達其實踐意見。研究員亦利用問卷收集學生對此模式的觀感。結果顯示教師的主要困難是教學前的計劃和準備。學生對此模式 亦持正面評價。此等結果給予體育教師及教師培訓多方面啟示。

\section{Introduction}

Sport education is one of the pedagogical models that has attracted attention and interest from physical educators and researchers recently. There have been a growing numbers of sport education research literatures being published. In a recent retrospective article on sport education, Siedentop (2002) indicated that over 50 articles on this topic now exist within the literature. These publications have helped physical education teachers understand the rationales, the benefits and the implementation of sport education, (Hastie, 1998a; Kinchin, 2001; Kinchin, Quill, \& Clarke, 2002; Siedentop, 1998). Indeed, this pedagogical model has been well received within the field of physical education in some western countries (Alexander \& Luckman, 2001; Grant, 1992; Hastie \& Buchanan, 2000; Kinchin, Penny, \& Clarke, 2001). However, when teachers facing new teaching approach, they might have anxiety and hesitancy when implementing, this is especially true when the new 
approach differs from the traditional one (Barret \& Turner, 2000). Sport education is being seen as a new and innovative pedagogical approach for Hong Kong physical education teachers. By reviewing the local physical education journals, there is limited study being published on this topic. Some serving physical education teachers even came to know this approach only when attending a physical education professional development seminar conducted by Education Manpower Bureau in 2005. In the seminar, a secondary physical education teacher shared her experience in implementing sport education in her school. The teacher alerted that there might be pedagogical difficulties and resistance when first introducing the model in school. Anyhow, she commented that this innovative model might be an alternative to motivate and help our students learning in physical education lessons.

In this paper I drew on recent research experiences and data from two Hong Kong secondary schools to support our contention that the implementation difficulties would be faced when first introducing this pedagogical approach in schools. Specifically, a range of factors should be carefully considered when implementing the sport education model. In so doing some of the implications were addressed in order to help further research and development of sport education programmes.

\section{Sport Education}

Sport education is concerned to establish connections between curricula, teaching and learning in physical education and characteristics of wider context of sports. It is also concerned both the development of performance and providing children with skills, knowledge and understanding that relate to authentic sport involvement. Siedentop (1994a) pointed out that this model emphasizes the inclusion in physical education and encourages students to take responsibilities for their own and others' learning. Within this learning process, students are urged to think critically about some aspects of sport in society and some of the behaviours seen in sport that we may not wish to reproduce.

According to Siedentop, sport education has a number of defining features and goals. As it aims to promote positive sport experience for students, all students will go through several key contextual features of authentic sport (Siedentop, 1994b). These characteristics include: a) sport is done by seasons; b) players are members of teams and stay on that team for the whole season; c) seasons are defined by formal competition, which is combined with teacher and student directed practice sessions; d) there is a culminating event that makes the end of each season; e) there is extensive recording keeping and collection of statistics and used for purposes of feedback to individuals and teams; and f) there is a festive atmosphere to celebrate success by using team names and uniforms and so forth in which the season takes place. Through these authentic experiences, sport education helps students to become competent, literate, and enthusiastic sports players. An important characteristic of sport education is its encouragement to extend student learning and experiences via opportunities and responsibilities to undertake a variety of non-playing roles associated with the learning activity. Accordingly, students will take on the roles of captain, coach, official, statistician, journalists and so forth. These additional opportunities can be created to extend learning and engage students with skills, knowledge and understanding in relation to participation and performance in sport as a player or athlete. Moreover, students are expected to take greater responsibility and accountability progressively for their own learning both individually and collectively. Throughout the season students will be requested to work cooperatively to appreciate and understand their individual and collective strengths and weaknesses in terms of performance and participation.

Sport education's conceptual roots were derived from play education, with Siedentop (1980) arguing that the meaning and potential of physical education was best explained in reference to the concept of play. Siedentop (2002) suggests that play can engross participant in a powerful and complete manner. He argues that play can stimulate student engagement and encourage them to be physically active the rest of their lives. Numerous research studies have emerged to support the implementation of Sport Education in Australia (Alexander, Taggart, \& Thorpe, 1996), New Zealand (Grant, 1992), England (Almond, 1997; Kinchin, et al., 2001) and the United States (Carlson \& Hastie, 1997; Hastie, 1996, 1998b, 2000).

Much of the research findings from the sport education studies indicate that many results replicate across different subjects and settings. Siedentop (2002) indicates that these findings are more similar than different. The following is a brief summary of some findings from specific studies: (a) some students preferred sport education and favoured this model when compared to the traditional approach of PE (Carlson \& Hastie, 1997; Hastie, 1998c); 
(b) students appreciated the socializing effects within team membership and affiliation of sport education and achieved learning outcomes (Carlson \& Hastie, 1997); (c) students liked and fulfilled their non-playing roles seriously and gained related knowledge during the process (Hastie, 1996); (d) some students were found actively participated and engaged in sport education units (Alexander, Taggart, \& Medland, 1993); (e) lower skilled students gained confidence and felt more positive and accepted by team members (Carlson, 1995); (f) high-skilled learners become more patient and considerate of others (Kinchin, 2001); (g) sport education reinforced game skills in invasion games (Hastie, 1998b); (h) some students assured their learning experiences as authentic and meaningful (Kinchin \& O'Sullivan, 2003); (i) learners exhibited better game performance when compared to units taught using traditional teaching models (Ormond, DeMarco, Smith, \& Fisher, 1995); (j) teachers uphold the adoption of the model (Alexander \& Luckman, 2001; Grant, 1992).

On the whole, these findings are mostly positive. Nevertheless, implementation of sport education in some contexts has been with difficulties and resistances. Some girls have reported that there are dominations by males during competition and inequitable opportunities to fulfill some non-playing roles (Hastie, 1998b). Researcher also indicates that some students refuse to take responsibilities and cooperate with others (Brunton, 2003). In a recent local case study, similar learning phenomenon was also observed. The local physical education teacher also suggested there might be contextual problems when carried out the model in Hong Kong school environment (Chan \& Cruz, 2006). It seems that we still have much to understand why sport education do not work in some settings and what might be difficulties which appear during implementation.

Sport education model is new to Hong Kong physical education teachers. The investigator learns that only few physical education teachers have attempted to implement this model in the last few years. Most of these teachers are in fact the in-service student teachers studying in a local institute of education and learn the model from their in-service teacher education professors. Their experiences in implementing the model will influence their future practice of the model. To date there is few local researches studying the implementation of sport education, it is worthwhile for the investigator to start conducting research on this topic in Hong Kong.
As the sport education model is well received in most western countries, it seems that this model is a promising approach. Therefore, one of the purposes of this study is to examine the challenges the teachers may face when implementing the sport education model. Besides, the investigator is also interested to know the views of students and teachers from their learning and teaching experience within the model. The findings generated are valuable to the physical education practitioners and teacher educators if they want to implement or promote the practice of the model. In order to achieve the above objectives, two research questions are set to guide the inquiry of this study: 1) What are the difficulties of implementing the sport education model in Hong Kong? and, 2) How do the physical education teachers and students perceive the model?

\section{Methods}

In terms of the research methodology, a qualitative approach and multi-methods were used in the study (Robson, 1996). The following research tools were utilized: (a) participant observation of lesson; (b) field notes taken during sport education lessons; (c) a teacher reflective journal; (d) questionnaires to students; and (e) semi-structured interview with teachers. Observations were used to help the fidelity of sport education. Field notes provided evidence that the teachers deliver an accurate reflection of the model, while allowing issues that needed to be further explored to be identified. Views of the teachers were gained through individual interviews as well as on the reflections on the journals. Students' perceptions on the sport education were also collected from the questionnaires. Questions were phrased to find out about the learning experiences of the students from the sport education lessons. Triangulation was carried out to check the consistency of findings generated by different data collection methods. The credibility and trustworthiness of the data were strengthened due to the generation of data from multiples sources (Hastie \& Buchanan, 2000).

\section{Subjects}

The participants for this study were two secondary school physical education teachers and 110 secondary school students in their schools. The participants were purposely invited to take part in the study as they were the teachers who had tried the sport education model in their teaching. Due concern was paid at all stages 
of the research to ethical issue, including permission to undertake the study, the maintenance of confidentially and the protection of the identities of both students and teachers.

Permissions were sought from their school principals and consent forms were completed by the two teachers. All teachers obtained their Qualified Teacher Status and were trained locally in teaching physical education. At the time of data collection, they were pursuing their undergraduate degree in one local institute of education in-service BEd training programme. Their physical education teaching experiences ranged from 3 to 6 years and they were rich in ball games knowledge background as coaching football in their respective schools.

\section{Data Collection}

The two teachers were asked to teach a unit of games lessons in the sport education model approach to two classes of students in their own school. Data were collected once the teachers started their teaching. The teachers were asked to keep a reflective journal that focused on their perceptions about the process of implementation the sport education approach as well as the responses of students to this teaching model in the lessons. The investigator also observed at least half of unit lessons of the teachers in the sport education model and field notes were taken during each entire lesson. Particular attention was paid to the instructional practices of the teachers and the learning of students. Learning tasks, interactions with students and student learning were recorded. A post-teaching interview was conducted with each teacher individually within one week after their teaching of the units. An interview guide approach (Patton, 1990) was adopted. A set of open-ended questions was developed to use as a guide during the interview as to ensure all pre-topics were covered with every teacher. The list was used to focus on their views of using the sport education approach in their teaching and to gather the richest information from the participants. The questions were about (a) their initial concerns and preparation for teaching; (b) change of their teaching role; (c) the selection process for the teams and captains; (d) assessment; (e) student roles and their responses to undertake the responsibilities; (f) students' attitudes, skills and social development, knowledge of techniques, game strategies and rules learning. The interviews were audiotaped and later transcribed verbatim for analysis. All interviews lasted between 45 to 60 minutes.
Views of students were also obtained through the use of a structured questionnaire with open-ended questions at the end of the teaching unit. The questions were modified from Clarke and Quill's study when collecting students' view on sport education (Clarke \& Quill, 2003). These questions focused on the student's perception toward the effectiveness of the instructional approach. The content validity of the student questionnaire was developed by consulting one experienced physical education teacher in a local institute of education. Besides, the questionnaire was independently read by the two teachers to determine if the language of the questions was clear and appropriate for their students. No suggestions were made. Questions mainly address: (a) how they felt about having a role; (b) how members of their team responded to them if they had a role; (c) if they didn't have a role whether they would like to have one; (d) how they felt about the selection of the teams; the captains and other roles; (e) if they were enjoying PE more; learning more; and feeling more confident to join extra sports activities; (f) how their team worked together during the lessons; (g) relationships in the team; (h) what their team did well together and also those not very well; (i) what they liked and disliked about working in a team; $(\mathrm{j})$ to sum up their feelings about the unit if they wanted to suggest ways that might help to better suit their interests. In fact, the teacher interview questions and student questionnaire were piloted and administered before the start of the study. A secondary physical education teacher who had tried the sport education approach was interviewed and 10 of his students were asked to fill in the questionnaires. The data collected during this pilot run indicated that the teacher interview questions and student questionnaire were valid for the study. The two teachers helped to collect the survey questionnaires from all student participants in their own school. 83 Form two and 27 Form six student questionnaires were returned and the response rate was $100 \%$.

\section{Data Analysis}

Data were organized and analyzed through inductive analysis and constant comparison (Denzin \& Lincoln, 1994; Miles \& Huberman, 1994). Transcripts from field notes, individual interviews, student questionnaires and teachers' reflective journals were reviewed, re-read and analyzed. Re-occurring categories and topics were combined to form larger themes where necessary. Findings from field notes, teachers' reflective journals, interviews and questionnaires were compared and contrasted to cross-check data and 
interpretations. Consistent findings from different sources coupled with good explanations for differences in data from divergent sources enhanced the overall credibility of the study results. Besides, the investigator also shared the developing categories with the teachers to check for accuracy and further elaboration. Lastly, an institute colleague who knew the teachers and was familiar with sport education was asked to share interpretation and data and acted as peer debriefer of the study.

\section{Results and Discussion}

The major purposes of the study were to understand the difficulties the teachers may confront when implementing the sport education model as well as the views of teachers and students on this model. Data analysis indicated that the challenges raised by the two physical education teachers were based on the following categories: (a) planning and organizing, (b) role changing, (c) lack support, (d) environmental constraints, and (e) students' roles taking. Their overall views on the model were positive: (a) student learning, (b) preparation and setting, and (c) professional development. While the views of the students on the model included both positive and negative. The positive perceptions of the students were categories into themes: (a) approach recognition, (b) enjoyment, and (c) request while their negative impressions were (a) lesson theme, (b) experiences and (c) settings.

\section{Difficulties faced by the teachers when implementing the model}

Planning and Organizing. The two teachers admitted that they were used to teach in skill-based approach and adopted the multi-activity model in schools. Introducing innovative model into their daily practice is a new challenge to them. They pointed out that implementing the sport education model was not an easy task. Although they had tried the model before, they were not familiar with the planning of the unit and the organizing of the lesson activities. Both teachers understood that designing appropriate learning activities was important to student learning but they did not have much confidence during preparation.

My main concern was on the preparation of the teaching plan. ... h had expected that there would be a lot of difficulties....it was quite difficult to design appropriate game activities...Apart from this, time arrangement for activities was also a hard job for me. (Teacher A)
My main worry was how to organize the students to arrange an activity. Since they were lack of experience in organizing activity, it was difficult for them to organize a well-arranged competition. (Teacher B)

Other teachers who had tried the model in some western countries also shared the same experiences. Hastie (2000) commented that teachers might face challenges when delivering sport education in school. They need to develop a strong management system as well as establishing a number of protocols. New introduced tasks need to be taught formally and practiced early. The success of the sport season will depend on how well students can perform their non-playing roles.

Role Changing. With the gradual handing over of instruction responsibility to the students in sport education, the teachers found that they had changed their teaching roles in the lessons. The teachers moved from a more dominant teaching style to a facilitative style as the season progressed, allowing students to take responsibility for their learning, such as taking up warm up, practices, organizing training and matches. The teachers increasingly became facilitators of teaching and learning.

I think my role had changed....apart from observer, I assisted their learning.......whenever they had problems and arguments I would do something to help them....I had more time to take care of their individual differences in learning....(Teacher A)

My role had changed to a facilitator and encouraged them to learn. (Teacher B) Both teachers shared the same view that the teachers' role changed from directive to advisory and the students changed from passive to active. The students became more active and engaged in the learning and the teacher turned into more passive role in instruction. Similar teaching phenomenon was also observed by Hastie (2000) in his study. He reported that the teachers spent more time refining and extending task, peer coaches spent more time in organization, demonstration, and application tasks. Teachers need to monitor the tasks that peer coaches implement in the lesson. The usual instructional roles of teachers had been changed when adopting the sport education model It seems that physical education teachers need to expect role changing within this teaching model. Besides, the teachers remarked that there was more work in preparation than before. They need to prepare the contingency 
plan, reference materials for students as well as the new evaluation forms required for the model.

I think the preparation work were much more when compared with my previous teaching...I had to prepare some information on organizing tournament for them (students). (Teacher A)

...it was different from the past, I had a lot of plans and contingency work to prepare...to conclude, the preparation work was really very difficult. (Teacher B)

Lacking Support. Front line teachers play an important role in implementing innovative changes (Fullan, 1992)). They need to get support when initiate these new moves in school. Siedentop (2002) mentioned the importance of having good practical materials to start sport education in their planning and teaching. In the present study, both teachers admitted that they learnt the sport education model from their in-service teacher education professors. They appreciated and understood the principles and theoretical background of the model. However, they claimed that they did not have sufficient support when carrying the model in school. They complained that there was limited local reference on sport education. This was one of the major difficulties when they initiated the model in schools. What they could do was to seek advices from their institute professors. Therefore, the two teachers made similar comments:

The model was new to them and there was not much local reference and support on sport education. (Teacher A)

At this moment, there isn't any local teaching plan of this model for reference. My main source of reference was from foreign countries. (Teacher B)

It is likely that local physical education teacher educators and researchers need to produce local references and organize professional development workshops in order to help promoting this innovative model. Besides, Tozer and Horsley (2006) argued that lacking resources for teachers' professional development would make the practitioners rarely have the chance to think together about how to improve the physical education instruction. Collaboration between education institute and school teachers seems to be the future direction when implementing the sport education model in school.
Environmental Constraints. Siedentop (1994b) suggested teachers should introduce sports they knew well when start adopting sport education in order to ease their instruction in skill and tactics. Both teachers chose football as their teaching contents as they were well experienced in teaching and coaching football. However, teachers might still have some school constraints when implementation. Teachers in the present study found that they need to adjust their curricular design in terms of sequence and balance. Sport education units are longer than that typically seen in many instructional models enabling a focus upon tactics and time for students to learn. The adoption of extended units might have disturbed curriculum planning of the teachers in the present study as this was different from their traditional practices. Penny, Clarke, Quill, and Kinchin (2002) discussed a range of factors that might influence activity selection as the basis for individual sport education units. These included equipment, facilities, timetabling, staff expertise, pupil familiarity with the content, and the ability to address issues of equity and inclusion. In fact, some of these listed factors also acted as school constraints and influenced the implementation of the model in the present study.

When I adopt the sport education model, the planning needs to match up with the school PE yearly curriculum content...I had to devise a way to avoid influencing our yearly teaching contents...At most, I could only assign six double lessons for the sport education model... Besides, I have to consider whether it is suitable to the tradition of our school...in many cases, the department head may not understand the model and think you are not teaching seriously and just let the students play freely. I might need to explain to the department head before starting. (Teacher B)

I had used nine double lessons for the model...since my school was having improvement work construction, we were forced to have PE lessons outside school... Weather might influence my teaching. I had to conduct my lessons in school basketball courts for football lessons during rainy days and it was totally ineffective...I prefer to have bigger playing area for teaching football with sport education model.. the time for teaching sport education was very short even with nine double lessons. I think nine double lessons are not enough. (Teacher A) 
Apparently, individual school facilities and time allocations were two major environmental constraints in the present study. Thus, physical education teachers are advised to be more flexible in order to overcome their school contextual limitations when starting the new practice (Siedentop, 1994a).

Students' role Taking. Although the opportunity of students to take on different roles in the lesson as a feature of sport education has been supported (Hastie, 1996; 1998b), field notes indicated that some students did not perform their roles seriously. The teachers also noted that there were few students showing no interest and did not like to take up responsibilities in the lessons. The data of the student questionnaires also confirmed that some students dislike being assigned duties and preferred not having a role in the lessons. They viewed these assignments as troublesome and boring. They did not feel good when taking duties. Some even said that they did not want to take part in the lessons. Similar student responses were also reported in other studies (Brunton, 2003; Clark \& Quill, 2003; Curtner-Smith \& Sofo, 2004). Fortunately, all these responses were only from a small number of students in these studies. It is possible that these students were "lower skilled students" and being "left out" in the lessons (Hastie, 1998c; Kinchin, Wardle, Roderick, \& Sprosen, 2004; O'Donovan, 2003). It is a challenge for teachers to motivate these students to participate in sport education lessons. Understanding and fulfilling these student needs will be the major tasks of the physical education teachers when applying sport education in future.

\section{Positive perception of the physical education teachers}

Most teachers who had tried the sport education model supported and maintained it within the school curriculum (Alexander, et al., 1996; Alexander \& Luckman, 2001; Clarke \& Quill, 2003; Curtner-Smith \& Sofo, 2004; Grant, 1992). The teachers in the present study also shared similar perceptions after trying the model. Their perceptions of the model were positive and excited when they first learnt the model from their institute professors. Both teachers claimed that the responses of their student to their traditional teaching approaches were not good. They thought the students would like the new approach and add excitement to their teaching. They would try the new model to excite the students' responses. From the implementing experiences, their overall views on the model were positive:
Student Learning. The teachers believed that the model would benefit the students. They thought that sport education could enable the students to learn actively and help to develop creativity as well as enhancing their cooperation during their learning process. After the units, they found most students well accepted the new model. They actively involved and enjoyed the learning activities. From their observations, the students did learn from the model.

From their performances in the competition, I noticed that they could apply some of the learnt knowledge.....they could apply some of the learnt football skills in the games...they demonstrated good sportsmanship and team spirits.(Teacher A)

Some students could perform the football skills and most did improve their social skills....they learnt communication skills and cooperation skills and I found that they benefited from social development. (Teacher $B$

From the responses of the students in the lessons, the teachers supported that the students cooperated better among each others and could apply their skills in the games under sport education. They further pointed out that the students might develop generic skills such as communication, cooperation and problem solving skills among themselves within the sport education season. In one of recent local studies, students also exhibited the improvement of some generic skills under the sport education model (Chan \& Cruz, 2006).

Preparation and Setting. The teachers treasured their experiences when implementing the model. They admitted they need to re-adjust their preparation and setting according to the reaction of the students. They would try the approach more strategically in future. They argued that the sport selected in the model might influence the learning of the students. They trusted better planning in future would help students learn better. They identified ways of improvement from their implementing experiences this year.

From this year experience, I will have a more detailed plan next year. I will plan the rundown of the whole unit....I will deliver the model in a bigger teaching venue...I will provide sufficient time for the students to coach and organize.... and extend the unit lessons... (Teacher A) 
Since this was my second time to try the model, my planning was better...I knew how to seek related information and advices for the institute supervisors.... From this experience, I learnt some managing skills and how to guide the students...I believe that I will do better in the coming year if I spend more time in preparation... I would consider the sport selected for the model as some may not be interested. I would choose a more popular sport which suits most of the students.... (Teacher B)

It seems that both teachers are confident in adopting the model when they have more experiences. They believe their success of implementing the model will depend on their effort in planning.

Professional Development. The teachers remarked that they tried the new model because of the changing responses of their students to their teaching in recent years. They raised that they had to learn new physical education methodologies as to excite the learning of the students in schools. Both teachers held strong beliefs in their profession and were willing to try new ideas in their teaching. As one of the teachers said, "I want to try some new methods and see the responses of the students". At the end of the units, the teachers admitted that they had gained a lot after trying the model. They understood more about model and its application. They found the students benefit from the sport education and started realizing the different learning needs of them. They were willing to try the model again.

I learnt how to plan an innovative curricular model.....apart from teaching skills, we also need to help students develop both cognitive and affective domains...I started to realize different needs of each individual....each might have different abilities on sports, and we had to know how to take care of their individual differences. (Teacher A)

I learnt that I need courage to try the new things...... understand more about sport education after trying them twice....I learnt how to guide and direct my students to organize competition within the model....This attempt was a real good experience!...I understand that traditional teaching model should be changed according to the needs of my students....we should try different kinds of instructional models.... and enable our students to learn happily. (Teacher B)
It is obvious that both teachers gained professional development during their practices. O'Sullivan and Deglau (2006) explained the roles of teachers on their professional development, "we did expect them (teachers) to try the ideas presented and, with experience and reflection on what happened, to discuss these experiences, and to adopt, revise, adapt or rejected the ideas presented" (p. 444). In the present study, the teachers developed their own knowledge in practice through their instructional experiences and reflections. As a result of professional development experiences, the teachers have polished and changed their teaching practices.

\section{Positive views of the students on sport education model}

Most students were in favour of the model based on the observations of the teachers. In fact, the overall responses of the student questionnaires also gave similar indications. Although not all students completed the questionnaires in details, most of them gave their major views on the model. The students' major views on their model were shown on Table 1. 70 students clearly indicated that they liked to be assigned duties and responsibilities in the model. 36 students praised the model and claimed that they learned a lot from the new experiences. 32 students appreciated and enjoyed their learning experiences and 14 student requested teacher to adopt similar teaching approach in future. 
Table 1. Major Views of Students on Sport Education.

\begin{tabular}{lcccccc}
\hline & \multicolumn{2}{c}{ F. 2 (N=83) } & F. $6(\mathrm{~N}=27)$ & \multicolumn{2}{c}{ All (N=110) } \\
Views & 49 & $59 \%$ & 21 & $77.7 \%$ & 70 & $63.6 \%$ \\
Favour and like to be assigned duties & 10 & $12 \%$ & 5 & $18.5 \%$ & 15 & $13.6 \%$ \\
Dislike being assigned duties & 26 & $31.3 \%$ & 10 & $37 \%$ & 36 & $32 \%$ \\
Learn and benefit from the model & 7 & $8.4 \%$ & 7 & $25.8 \%$ & 14 & $12.7 \%$ \\
Request & 23 & $27.7 \%$ & 9 & $33.3 \%$ & 32 & $29 \%$ \\
Good Experience & 9 & $10.8 \%$ & 4 & $14.8 \%$ & 13 & $11.8 \%$ \\
Negative Impression/ Experience & & & & & & \\
\hline
\end{tabular}

The perception of the F. 2 students on the model were similar to those of the Form six counterparts. However, it seems that the upper form students like the model more as more students showed more preference for it. When further analyzing the responses of the student questionnaires, three positive themes emerged:

Approach Recognition. Students recognized the approach was new and different from their previous learning format. Most of them liked to be assigned duties and responsibilities. Through these delegations, they learnt within their roles.

Being assigned duties, I understand how to manage a competition...

To be assigned duties will help to develop my responsibilities, organizing and managing abilities...

I love to be recorder and I can have more time to cheer my team up...

I like to be assigned duty, I treasured the experiences and learnt the importance of different posts...

I was assigned as coach and I learnt how to organize training...

Most of the students felt excited and interested when being assigned responsibilities. Some took leadership roles and fulfilled the duties seriously. These students were more involved in the learning process and demonstrated a strong sense of ownership and determined to succeed (Clarke \& Quill, 2003). It seems that the sport education model fosters the development of autonomy and initiates the students to participate in the learning activities. As in other studies, some students had taken the roles seriously and actively engaged in the lessons (Brunton, 2003; Chan \& Cruz, 2006; Hastie, 1996). Eventually, these students were benefited from these role taking experiences (Hastie \& Sinelnikov, 2006; Kim, Penny, Cho, \& Choi, 2006). The students in the present study reflected that they learned more about the about football, especially the organization of competition. The students recognized the learning of responsibility and the importance of team work within the learning process. They also valued the learning experiences, especially on the assigned duties and participation in the competition. In short, the students enjoyed taking on different roles on their own.

Enjoyment. The two teachers reported that some students really enjoyed their responsibilities and most students actively and seriously participated in the lesson activities. These student responses were rarely found when they were taught in traditional skill-based approach. From the responses on the student questionnaires, they showed that they favoured the sport education model as they experienced fun in the season. They highlighted the model was different from the traditional skill-based lessons. They had more games and competition than before.

It was a good experience. I liked playing as a team and I was having fun... learnt team spirit.

At first, I did not want to participate...in the midst of the season, I experienced the happiness of being a team member in my team...

The model was fun, it enhanced friendship, cooperation and communication... 
It was not boring as in our traditional PE lessons...I felt happy and having fun.

It was great fun and I learnt how to be a referee.

It was good experience... I was happy when I played games with my friends.

It was great fun in these learning experiences.

Most students were pleased with their learning experiences. This may explain why they actively responded in the lessons. In fact, student enjoyment was a typical feature found in most sport education studies (Clarke \& Quill, 2003; Hastie \& Sinelinikov, 2006; Kim, et al., 2006). This fun dimension may be related to the skill and social characteristics of the model. As the students enjoyed their learning experiences, they would like to participate in similar PE lessons. Therefore, the sport education is an attractive curriculum and instruction model to most students.

Request. Students preferred sport education to their previous physical education had been reported in a number of studies (Alexander, et al., 1993; Brunton, 2003; Carlson \& Hastie, 1997; Grant, 1992). Some students in the present study also expressed a wish to have sport education in future physical education. They cherished these experiences and requested for more.

It is better to have longer period for these learning experiences.

If more PE lessons can be taught like this, I think more students will like PE the best.

The unit was too short and I enjoyed less...

I was fun and I wish to have these experiences next time too...

This was my first time to participate in football competition and I wish to have more in future.

I really enjoyed it and I wish to have these experiences next time.

It is likely that the students had learned and played well with their classmates in the season. They appreciated they spent some time to work with their teammates and understood each others. The new model was well received by most of the students.

From the responses of the student questionnaires, few students claimed that they had negative impression and experiences in the season. They pointed out the teacher could have better prepared and avoid these unfavourable experiences.

\section{Negative views of the students}

Long theme. Learning within long extended units is one of the major characteristics of sport education. Students indicated that the long extended unit provided more time for them to play and learn one particular activity as well as socially interact with team-mates (Alexander, et al., 1996; Brunton, 2003; Kinchin \& O'Sullivan, 2003: Kinchin, et al., 2004). However, some might feel bored and showed no interest in the long unit if they did not like the selected sport in the season. Some voiced out their negative views:

The sport for the unit need to be more popular and everyone knows how to play...

The unit was too long and this minimized my opportunities in learning other sports.

It was a bad experience as I do not like football.

Indeed, Penny and his associates (2002) have argued that activity selection plays an important part in influencing how the students learn in the sport education season. They suggested that the choice of activity should be compatible with students' cultural backgrounds and addressed the issues of equity and inclusion in the season. Recently, Kim and his associates (2006) pointed out that the teacher in their study had offered choices to their students and selected activities received most student support. This served as a practical strategy to increase student interest and motivation for active participation in the season and various roles assigned. One of the teachers in the present study also noticed that he should choose a more popular sport in future in order to satisfy the needs of majority students.

Bad Experiences. A small numbers of students reported that they had negative experiences and were badly treated during the sport education season (Hastie, 1998c; Kinchin et al., 2004). Similarly, some lower form students in the present study also raised that they had unfavourable experiences in the season.

I did not play well and my poor performance made my team lose.

I had a bad experience and it was too troublesome when fulfilling my roles and responsibilities.

I did not play well and not feeling good... I got frustrated.

It was wasting time... I was badly treated by my team-mates...I know I am not good enough... 
It seemed that some student felt left out or were badly treated by team-mates. These students obviously did not enjoy the sport education experiences. As Kinchin and his associates (2001) remarked that children took more ownership for their learning did not mean there would be no danger of marginalization and exclusion of some students in contexts of sport education. Teachers need to aware these students' bad feelings and should take an active measure when implementing the model in future.

Settings. Both teachers in the study claimed that the model was new to them although they had tried it before. They admitted that they also learned a lot from the implementation. The arrangement and the settings of the model could be improved and bettered next year. Some students commented that implementation of the model could have been better if the teacher played a more active role in the preparation.

The teacher could allocate more time for training and organizing more matches for us. Now, we had limited time and only had few matches.

We had limited playing areas and it was a waste of time going to other school playground.

The players were not serious and my team-mates were irresponsible. I think the teacher should play a more proactive role.

The referee judged poorly and the teacher should help and correct his judgment.

The teacher's planning was not good enough...some of us did not know what to do.

...feeling of confusion and misunderstood some duties the teacher assigned.

Some team-mates did not cooperate well and we need advices from the teachers.

It seemed that some students were expecting their teachers to play a more active role in teaching and intervene if necessary. Nevertheless, the teachers wou2ld learn from their responses and implement the sport education more strategically next year.

\section{Implications}

Although the findings of the present study were generated from the views of two local physical education teachers and their 110 students, they still hold several implications for the practice of physical education. Since both teachers and most students gave favourable views on sport education, it implied that the model was well received by them. In fact, the results are consistent with reports from students and teachers in some western studies (Alexander, et al., 1996; Carlson, 1995; Grant, 1992; Hastie, 1998c). This study adds weight to an argument that sport education is an empirically supported curriculum model for Hong Kong school physical education.

When implementation, the teachers raised that they did face several difficulties even they had tried the approach before. It is likely that trying innovative model in the daily practice is not without problems. However, both teachers were confident in overcoming these difficulties if they had prepared better. It seemed that they had learnt from the implementation. Therefore, it is advised when start trying the model, the teacher should choose one or two small size upper form classes to experiment. It is expected that implementing curricular innovation will take time and continuous experimentation. To start it "small" will minimize the challenges that may face and increase the confidence of adopting the model.

Kim and his associated (2006) commented that the challenges of the introduction of sport education were ongoing. Both the teachers and students in their study had progressed and changed the responses over four seasons of sport education. The teacher in the study had increased her pedagogical knowledge enormously with reference to the implementation of sport education over the seasons. Rovegno (2003) argues that experience plays a critical factor in learning to teach. In the case of the teachers in the present study, they constructed their knowledge through the experience of implementation as it helped them to understand theory in practice and theory through practice. These all implied that teachers need to be provided with ample opportunities to experience and practice the model before implementing in school. Education Bureau and teacher education institutes should work together and provide in-service training workshops for the practicing teachers. On the other hand, the teacher education institute should also provide training to their pre-service student teachers to adopt sport education in teaching. The student teachers should be encouraged 
to try the model during their student teaching experience in schools. Local academics are also encouraged to produce supporting sport education materials for practicing teachers. The availability of practical materials will assist teachers in their planning and teaching. Once the teachers understand more about the practice of sport education, they will have confidence and willing to try the model in their teaching.

The results generated in the present study need to be cautiously interpreted as it has been carried out on a small scale with limited participants. The relatively short duration of the sport education season with six to nine weeks is also another limiting factor in drawing conclusions from the study. Therefore, it is advisable to include more school teachers and students with different sport activities in long extended units in future study. This may help to give a better picture of how the teachers and students respond to the new model.

Lastly, as there were few students expressed that they had negative impressions or experiences in sport education, it is necessary to further investigate how to "entertain" these small number of students and include them in the learning process of the sport education season. Indeed, more local studies of applying the sport education in teaching are needed. The findings will help us know more about the application of the model in local contexts.

In conclusion, the sport education was well perceived by the teachers and students in the study. Although there might be difficulties when first implementing, it is worthwhile for the local physical education teachers to adopt the model as it is a promising alternative instructional model in teaching physical education. Implementing sport education with success is neither guaranteed nor quickly achieved at the present moment, however, the Hong Kong physical education teachers will soon learn its application if they have courage to try it in schools.

\section{References}

Alexander, K., \& Luckman, J. (2001). Australian teachers' perceptions and uses of the sport education curriculum model. European Physical Education Review, 7(3), 243-267.

Alexander, K., Taggart, A., \& Medland, A. (1993). Sport education in physical education: Try before you buy. ACHPER National Journal, 40(4), 16-23.

Alexander, K., Taggart, A., \& Thorpe, S. (1996). A spring in their steps? Possibilities for professional renewal through sport education in Australian schools. Sport, Education and Society, 1(1), 23-46.

Almond, L. (1997). Sport education in schools, in L. Almond (ed.), Physical education in schools ( $\left.2^{\text {nd }} e d.\right)$. pp. 34-51. London: Kogan Paul.

Barret, K. R., \& Turner, A. P. (2000). Sandy's challenge: New game, new paradigm (a correspondence). Journal of Teaching in Physical Education, 19(2), 162-181.

Brunton, J. A. (2003). Changing hierarchies of power in physical education using sport education. European Physical Education Review, 9(3), 267-284.

Carlson, T. (1995). "Now I think I can": The reaction of year eight low-skilled students to sport education. ACHPER Healthy Lifestyles Journal, 42(4), 6-8.

Carlson, T., \& Hastie, P. (1997). The student social system within physical education. Journal of Teaching in Physical Education, 16(2), 176-195.

Chan, K. L., \& Cruz, A. (2006). The effect of sport education on Secondary six students' learning interest and collaboration in football lessons. Journal of Physical Education and Recreation (HK), 12(2), 1322.

Clarke, G.., \& Quill, M. (2003). Researching sport education in action: A case study. European Physical Education Review, 9(3), 253-266.

Curtner-Smith, M. D., \& Sofo, S. (2004). Preservice teachers' conceptions of teaching within sport education and multi-activity units. Sport, Education and Society, 9(3), 347-377. 
Denzin, N. K., \& Lincoln, Y. S. (1994). Handbook of qualitative research. Thousand Oaks, CA: Sage.

Fullan, M. G. (1992). Successful school improvement: The implementation perspectives and beyond. Buckingham, MK., Great Britain: Open University Press.

Grant, B. C. (1992). Integrating sport into the physical education curriculum in New Zealand secondary school. Quest, 44(4), 304-316.

Hastie, P. (1996). Student role involvement during a unit of sport education. Journal of Teaching in Physical Education, 16(1), 88-103.

Hastie, P. (1998a). Applied benefits of the sport education model. Journal of Physical Education, Recreation and Dance, 69(4), 24-26.

Hastie, P. (1998b). The participation and perceptions of girls within a unit of sport education. Journal of Teaching in Physical Education, 17(2), 157-171.

Hastie, P. (1998c). Skill and tactical development during a sport education season. Research Quarterly for Exercise and Sport, 69(4), 368-379.

Hastie, P. (2000). An ecological analysis of a sport education season. Journal of Teaching in Physical Education, 19(3), 355-373.

Hastie, P., \& Buchanan, A. M. (2000). Teaching responsibility through sport education: Prospects of a coalition. Research Quarterly for Exercise and Sport, 71(1), 25-35.

Hastie, P., \& Sinelnikov, O. A. (2006). Russian students' participation in and perceptions of a season of sport education. European Physical Education Review, 12(2), 131-150.

Kim, J., Penny, D., Cho, M., \& Choi, H. (2006). 'Not business as usual': Sport education pedagogy in practice. European Physical Education Review, 12(3), 361-379.

Kinchin, G. D. (2001). A highly skilled pupil's experiences of sport education. ACHPER Healthy Lifestyles Journal, 47, 3-4.
Kinchin, G. D., \& O’ Sullivan, M. (2003). Incidences of student support for and resistance to a curricular innovation in high school physical education. Journal of Teaching in Physical Education, 22(3), 245-260.

Kinchin, G. D., Penny, D., \& Clarke, G. (2001). Teaching the National Curriculum physical education: Try Sport Education? British Journal of Teaching Physical Education, 32(2), 41-44.

Kinchin, G. D., Quill, M., \& Clarke, G. (2002). Focus on sport education in action. British Journal of Teaching Physical Education, 33(1), 10-12.

Kinchin, G. D., Wardle, C., Roderick, S., \& Sprosen, A. (2004). A survey of year 9 boys' perceptions of sport education in one English secondary school. Bulletin of Physical Education, 40(1), 27-40.

Miles, B. M., \& Huberman, A. M. (1994). Qualitative data analysis: An expanded sourcebook ( $2^{\text {nd }}$ ed.). Thousand Oaks, CA: Sage.

O’Donovan, T. M. (2003). A changing culture? Interrogating the dynamics of peer affiliations over the course of a season. European Physical Education Review, 9(3), 237-252.

Ormond, T. C., DeMarco, G. M., Smith, R. M., \& Fisher, K. A. (1995). Comparison of the sport education and traditional approaches to teaching secondary school basketball. Paper presented at the annual meeting of the American Alliance for Health, Physical Education, Recreation and Dance, Portland, OR.

O'Sullivan , M., \& Deglau, D. (2006). Principles of professional development. Journal of Teaching in Physical Education, 25(4), 441-449.

Patton, M. Q. (1990). Qualitative evaluation and research method ( $2^{\text {nd }}$ ed.). Beverly Hills, CA: Sage.

Penny, D., Clarke, G., Quill, M., \& Kinchin, G.. (2002). Activity selection in sport education. Journal of Sport Pedagogy, 8(2), 53-66. 
Robson, C. (1996). Real world research: A resource for social scientists and practitioner-researchers. Oxford: Blackwell.

Revegno, I. (2003). Teachers' knowledge construction. In S. Silverman and C. D. Ennis (Eds.). Student learning in physical education: Applying research to enhance instruction (pp. 295-310). Champaign, IL: Human Kinetics.

Siedentop, D. (1980). Physical education: Introductory analysis. Dubuque, IA: W.C. Brown.

Siedentop, D. (1994a). Sport education. Paper presented at the SPARC-ACHPER Conference, Perth: Western Australia.

Siedentop, D. (1994b). Sport Education: Quality PE through positive sport experience. Champaign, IL: Human Kinetics.

Siedentop, D. (1998). What is Sport Education and how does it work? Journal of Physical Education, Recreation and Dance, 69(4), 18-20.

Siedentop, D. (2002). Sport Education: A retrospective. Journal of Teaching in Physical Education, 21(4), 409-18.

Tozer, S., \& Horsley, H. (2006). Professional Development of teachers in physical education-Where are we now? Journal of Teaching in Physical Education, 25(4), 450-457.

\section{Acknowledgement}

This study was supported by the Hong Kong Institute of Education small scale research grant.

\section{Correspondence:}

Dr. Alberto Cruz

Telephone: (852) 29487847

Fax: (852) 29487848

E-mail: acruz@ied.edu.hk

Department of Creative Arts and Physical Education, The Hong Kong Institute of Education

10 Lo Ping Road, Tai Po, New Territories, HONG KONG. 